University of Nebraska - Lincoln

DigitalCommons@University of Nebraska - Lincoln

Faculty Publications, Department of Psychology

Psychology, Department of

November 1997

\title{
Young Adolescents' Conflicts with Siblings and Friends
}

Marcela Raffaelli

University of Nebraska-Lincoln, mraffaelli1@unl.edu

Follow this and additional works at: https://digitalcommons.unl.edu/psychfacpub

Part of the Psychiatry and Psychology Commons

Raffaelli, Marcela, "Young Adolescents' Conflicts with Siblings and Friends" (1997). Faculty Publications, Department of Psychology. 56.

https://digitalcommons.unl.edu/psychfacpub/56

This Article is brought to you for free and open access by the Psychology, Department of at DigitalCommons@University of Nebraska - Lincoln. It has been accepted for inclusion in Faculty Publications, Department of Psychology by an authorized administrator of DigitalCommons@University of Nebraska - Lincoln. 
Published in Journal of Youth and Adolescence 26:5 (1997), pp. 539-558. Copyright (C 1997 Plenum Publishing Corporation/Springer Verlag BV. Used by permission. DOI - 10.1023/A:1024529921987 http://www.springerlink.com/content/k705560474x9286q

\title{
Young Adolescents' Conflicts with Siblings and Friends
}

\author{
Marcela Raffaelli ${ }^{1}$
}

Submitted July 1996; accepted March 1997

One hundred twelve white, middle class 10-14-year-olds participated in a descriptive study of conflict with their closest sibling and best friend. Analysis of questionnaire ratings (completed by all participants) revealed that frequency of conflict was significantly related to ratings of the friend's importance and satisfaction with the friendship but was not related to sibling relationship ratings. Descriptions of specific conflicts in the two relationships (provided by 81 youngsters) were compared to examine the onset, process, and aftermath of conflict. Conflicts between siblings and friends differed in how they were structured and experienced, suggesting that conflict functions differently in each relationship. The possible developmental implications of relationship differences in interpersonal conflict are discussed, and directions for future research identified.

\section{INTRODUCTION}

The study of interpersonal conflict has burgeoned in recent years, as theorists and researchers have examined the processes and outcomes of children's and

This research was supported by NIMH grant MH38324, awarded to Reed Larson. Data analyses were carried out and results written up while the author was a predoctoral fellow in the Clinical Research Training Program in Adolescence (CRTPA), jointly sponsored by the Center for the Study of Adolescence at Michael Reese Hospital and Medical Center and the Committee on Human Development at the University of Chicago, funded by NIMH institutional training grant number 2 T32 MH14668-12. Portions of this paper were presented at the Society for Research on Adolescence (March 1988), the Conference on Human Development (March 1990), and the Society for Research in Child Development (April 1991).

\footnotetext{
${ }^{1}$ Assistant Professor, Department of Psychology, University of Nebraska, 209 Burnett Hall, Lincoln, Nebraska 68588-0308. Received doctorate from the Department of Psychology (Committee on Human Development) at the University of Chicago. Current research interests include the developmental impact of homelessness, parent-child communication about sexual issues, and cultural influences on sexuality. Email: mraffaelli1@unl.edu
} 
adolescents' everyday disagreements and quarrels. Several interdependent approaches to the study of conflict have emerged. One focuses on conflict as a way of clarifying expectations and identifying important features of interpersonal relationships (e.g. Rizzo, 1989; Youniss and Smollar, 1985; Youniss and Volpe, 1978). Another approach examines how youngsters conduct and resolve conflict to assess levels of interpersonal understanding (e.g., Dunn, 1988; Selman et al., 1986). Finally, a third approach focuses on linkages between conflict interactions and psychological and social development (e.g., Berkowitz, 1985; Nelson and Aboud, 1985). These approaches converge in viewing conflict as a potential developmental force (Shantz and Hartup, 1992).

Much of the early work on youngsters' conflicts examined interactions between peers (e.g., Forman and Kraker, 1985; Hay, 1984; Piaget, 1932/1965; Shantz and Shantz, 1985). It is only within the last ten or fifteen years that the importance of interpersonal context in development has been recognized, and attention has shifted to examining patterns and outcomes of conflict interactions within different relationships (Berndt, 1989; Hartup, 1983). For example, researchers have examined adolescents' conflicts with friends as compared to non-friend peers (e.g., Caplan et al., 1991; Hartup et al., 1988; Nelson and Aboud, 1985); parent-child conflict has also been studied (e.g., Hill and Holmbeck, 1987; Montemayor, 1983). Different relationships have been linked to differences in the structure and outcomes of conflict interactions. Conflict in friendships has been linked to the development of social skills and interpersonal knowledge (Selman, 1981; Youniss and Smollar, 1985; Youniss and Volpe, 1978) and cognitive skills (Nelson and Aboud, 1985). In contrast, conflict with parents has not been linked to similar developments because unlike peers or friends, whose relationship is symmetrical, parents are more powerful than children and they tend to dominate interactions, evoking obedience and respect; because of this, conflict with parents is avoided or curtailed (Youniss, 1980; Youniss and Smollar, 1985).

Siblings represent a significant source of conflict for most children and adolescents (Bank and Kahn, 1982; Buhrmester and Furman, 1990; Dunn, 1985; Furman and Buhrmester, 1992; Lamb and Sutton-Smith, 1982; Montemayor and Hanson, 1985). Like friends, siblings provide companionship (Furman and Buhrmester, 1985a, 1985b); however, unlike friends, siblings usually differ in age, are bound by involuntary ties, and may or may not like each other as individuals. Interactions between siblings have been hypothesized to serve a variety of developmental functions (Tsukada, 1979), but the possible role of sibling conflict in adolescent development has been largerly ignored. In contrast to the developmental focus of research on peer and friend conflict, sibling conflict is 
typically discussed as the outward manifestation of unconscious processes of rivalry (e.g., Faber and Mazlish, 1987; Freud, 1955; for an important exception, see Dunn, 1988). The present study was aimed at describing and comparing conflicts between young adolescents and their siblings and friends.

The structure of conflict episodes has been described by a number of theorists and researchers (e.g., Berscheid, 1986; Hay, 1984; Shantz, 1987; Shantz and Hobart, 1989). ${ }^{2}$ A conflict episode can be conceptualized as a series of linked events falling into three stages: what is happening when conflict erupts ("onset"), what happens during the episode ("process"), and what happens afterwards ("aftermath"). Prior research on young adolescents' conflicts with siblings and friends suggests that the specific features of conflict in these two relationships differ (for a comprehensive review, see Collins and Laursen, 1992), although differences in methodology and definitions make it difficult to compare directly across studies.

The onset of conflict has been examined by a number of researchers. The precipitating action or cause of conflict has been most frequently studied; less is known about the social and activity settings in which conflicts occur. In one study, high school students reported that acting in an "untrustworthy manner" was the most frequent cause of conflict with friends, followed by "disrespectful acts" (boys) and "lack of sufficient attention" (girls; Youniss and Smollar, 1985). Rizzo (1989) has proposed that the two main themes of friends' conflicts are how interactions should be structured and how the relationship should be structured. Among siblings, two studies revealed that verbal exchanges and property disputes were common precipitants; quarrels over duties, chores, privileges or special treatment by parents were less frequent (Goodwin and Roscoe, 1990; Roscoe et al., 1987). Montemayor and Hanson (1985) found that most sibling quarrels were due to "interpersonal concerns" (teasing, extending courtesies, turn taking). Although different methodologies make it difficult to compare directly across these studies, it appears that friends quarrel over relationship concerns and issues arising from shared interactions, whereas siblings enter into conflict over issues of shared life and personality differences. Other aspects of the onset of conflict (e.g., social and interactional milieu) have not been studied, primarily because most studies obtain summary information about conflicts rather than descriptions of specific conflict episodes.

\footnotetext{
${ }^{2}$ Theorists typically differentiate between conflict, characterized by opposition and disagreement, and fighting, characterized by anger and aggression. In empirical research, this distinction is seldom made (Hay, 1984); as Shantz (1987) notes, in observational studies conflict is defined as overt opposition between individuals but in interview studies synonyms such as "fights" or "quarrels" are often used, suggesting that youngsters do not differentiate between conflict and fighting. In light of this, in this paper the words conflict, fight and quarrel are used interchangeably.
} 
How conflict is played out and terminated represents the second "stage" of a conflict episode. Most research on the process of conflict has focused on negotiation and resolution strategies. Among younger adolescents, boys tend to see aggression as an effective strategy for getting their way with friends, whereas girls use withdrawal or conciliatory measures (Crick, 1989). With age, adolescents (especially girls) use increasingly sophisticated problem-solving skills to resolve conflicts with friends (e.g., Selman et al., 1986; Yeates et al., 1991). In contrast, Montemayor and Hanson (1985) found that siblings typically used withdrawal and authoritarian procedures to end conflicts, and youngsters reported using physical force, reasoning, bribing, shouting, harassing, and crying to get their way (Sutton-Smith and Rosenberg, 1970; Roscoe et al., 1987).

The final stage of the conflict episode represents the dyad's attempt to restore the relationship to normal; relationship repair is considered an opportunity for developing sophisticated relationship skills as the dyad negotiates a reconciliation. When asked how they repaired their relationship with friends, girls described using overt strategies (e.g., apologizing, talking it out) and boys said they ignored the fight (Youniss and Smollar, 1985). Over half the youngsters interviewed by Sutton-Smith and Rosenberg (1970) said they resumed normal relations with their siblings by simply ignoring the conflict, and about a third of them said they would use an overt make-up procedure.

As this brief review shows, some aspects of adolescents' conflicts with siblings and friends have been examined but others are less well understood. One neglected area is how youngsters feel during and after conflict in each relationship; other features of conflict that have not been examined include structural aspects (e.g., duration of conflicts). One major limitation of prior research is that virtually no comparative studies of sibling and friend conflict have been conducted, making it difficult to compare across relationships and identify unique and common features of interpersonal conflict (Collins and Laursen, 1992). In this paper, descriptive information about young adolescents' conflicts with siblings and friends is presented in order to begin exploring the characteristics and functions of conflict in these two different relationships.

\section{METHOD}

\section{Sample}

Respondents were 58 boys (mean age 11.9 years) and 54 girls (mean age 11.6 years) who took part in a larger study of daily life during early adoles- 
cence (Larson and Richards, 1989). Participants in the larger study were fifthto ninth-grade students from two midwestern communities. One community was a middle class suburb on the edge of a large metropolitan area; residents were of primarily European origin, and most had moved from the city within the last decade. The majority of fathers commuted to white-collar jobs in the city, and two thirds of mothers also worked. The other community was an urban working-class neighborhood close to the city limits with a similar ethnic background. Fathers worked in blue-collar occupations, and nearly two thirds of mothers were employed.

The larger study was carried out over two years, with one wave of data collection each season. At each of the eight data collection waves, a randomly selected sample of students, stratified by grade and gender, was invited to participate. The subsample for the conflict study was drawn from the last two waves of data collection, carried out in the fall of 1986 and winter of 1987. One hundred forty-four fifth- to eighth-grade students were invited to participate in these two waves; 28 refused to take part and four had no siblings, leaving 112 students (78\%) who completed the conflict study. All 112 respondents completed questionnaires; a subsample of 81 completed an interview about a specific conflict with both their closest sibling and best friend (of the 31 respondents who did not complete the entire interview, 4 said they did not fight with either target individual, 4 said they did not fight with their sibling, and 22 said they did not fight with their friend). (For a full analysis of the sibling data, see Raffaelli, 1992.)

Respondents were divided into two age groups: 10-11 years old (43\%) and 12 or older $(57 \%)$. Sibling dyads were classified as same $(65 \%)$ or mixed (35\%) gender, and as closely (within two years; $27 \%$ ) or widely (3 or more years apart; $73 \%$ ) spaced. All best friends were of the same sex and $99 \%$ were closely spaced.

\section{Procedures}

Groups of randomly selected students met during school hours with a research team member who described the study and invited them to participate. Interested students were given information packets to take to their parents, who were subsequently contacted by telephone. Students who returned a completed parent consent/student assent form participated in the study. The larger study utilized the Experience Sampling Method and lasted a week. At the end of the week, participants were interviewed individually for about 45 minutes and were group administered a packet of self-report measures. Students were paid $\$ 8.00$ for participating. 


\section{Measures}

In addition to demographic information, two sets of measures were obtained for the conflict study: relationship quality ratings and descriptions of specific conflict episodes.

\section{Relationship Quality Ratings}

Two instruments were used to assess perceptions of relationships with siblings and friends.

Interpersonal Relations Questionnaire (IRQ; Blyth, 1982)

The IRQ has 14 items assessing four aspects of a specific relationship: emotional closeness ( 6 items; standardized item alpha .78 for siblings and .85 for friends); shared time (6 items; standardized item alpha .74 for siblings and .72 for friends); importance of individual (1 item); and relationship satisfaction (1 item).

\section{Interview Measures of the Relationship}

Participants were asked about two aspects of their relationships: frequency of conflict ("About how often do you and [name] get into fights or arguments?") and voluntary association ("How often do you spend time with [name] by choice?").

\section{Descriptions of Conflict}

The conflict interview was a standardized, open-ended interview developed for the present study. First, respondents were asked to name their closest sibling and best friend. Respondents with only one sibling answered questions with reference to that sibling. For youngsters with two or more siblings, interviewers asked if there was one sibling they felt closest to. If no sibling was identified, the sibling that was closest in age was selected. All further questions were made with reference to the target individual. The question of whether allowing respondents to select a target sibling resulted in biases has been addressed elsewhere (Raffaelli, 1992); few systematic effects emerged and no differences in frequency of conflict were found. 
During the interview, youngsters described a recent fight, argument, or disagreement with the target individual. Standardized instructions, probes, and follow-up questions were used to ensure comparable information across respondents. ${ }^{3}$ The descriptions were coded for 12 conflict variables capturing aspects of the onset (precipitating issue, whether the conflict was specific or habitual, social context, prior activity, instigator), process (duration, trajectory, emotional reaction, resolution strategy) and aftermath (time lapse before repair occurred, repair strategy, emotions after repair). Open-ended responses were classified into discrete categories; for most variables, the coding was straightforward and did not require inferences to be drawn (e.g., number of minutes conflict lasted; emotion named by the respondent). For three of the variables (precipitating issue, resolution strategy, and repair strategy), inductively derived coding schemes were developed from interview responses. These content codes were grouped into theoretically derived overarching categories, drawing on prior work on conflict and social interactions (Table I). Coding schemes were developed and tested by the author and a colleague, using one half of the interviews. Differences were discussed and reconciled, the codes were finalized, and a further sample of interviews was coded independently by the same coders. A final reliability check showed interrater agreement of over $90 \%$. Following this reliability check, the author coded the remaining interviews.

\section{RESULTS AND DISCUSSION}

Two types of analyses were carried out. First, questionnaire measures were used to compare the two relationships, and examine the interplay between frequency of conflict and other aspects of the relationship; this analysis draws on all 112 respondents. Second, descriptions of sibling and friend conflicts were compared, drawing on the 81 respondents who provided descriptions of a conflict episode within each relationship.

\section{Conflict and Relationship Qualities}

\section{Friends}

Means and standard deviations for ratings of friend relationship qualities are displayed in Table II. Preliminary analyses (not shown) revealed no significant differences in frequency of conflict attributable to age or gender composition

${ }^{3}$ Copies of the interview protocol are available from the author. 
Table I. Content Codes for Precipitating Issue, Resolution Strategy, and Repair Strategy

\begin{tabular}{|c|c|}
\hline \multicolumn{2}{|l|}{$\begin{array}{l}\text { Precipitating issue } \\
\text { Power issues }\end{array}$} \\
\hline Control behavior & $\begin{array}{l}\text { - I had the music turned up too loud, he told me to } \\
\text { turn it down } \\
\text { - I was on the phone with my boyfriend and I wanted } \\
\text { her to go out with his best friend but she didn't } \\
\text { want to }\end{array}$ \\
\hline Sharing/turns & $\begin{array}{l}\text { - Sunday he wanted to watch Disney movies and I } \\
\text { wanted to watch something else } \\
\text { - We alternate being in the front seat [of the car]. It } \\
\text { was my turn but he wanted to sit up there }\end{array}$ \\
\hline Personal property & $\begin{array}{l}\text { - She wouldn't give me back a little Garfield. She said } \\
\text { it's cute and she liked it so she wouldn't give it } \\
\text { back to me } \\
\text { - When I had to go to a dance and dress up like a girl I } \\
\text { wore her high heels and I broke them off and she } \\
\text { got really mad }\end{array}$ \\
\hline \multicolumn{2}{|l|}{ Abusive behavior } \\
\hline Psychological & $\begin{array}{l}\text {-I said I wasn't going to talk to her but I was just } \\
\text { kidding, and she got really mad at me } \\
\text { - When his girlfriend calls I always make fun of him }\end{array}$ \\
\hline Physical & $\begin{array}{l}\text { - Playing football, he got hurt. He blamed it on me } \\
\text { and my brother and friends } \\
\text { - This Monday during reading we got in an argument. } \\
\text { He was poking me in the back and I kept telling } \\
\text { him to quit it. He didn't stop, so when the teacher } \\
\text { wasn't looking, I hit him }\end{array}$ \\
\hline \multicolumn{2}{|l|}{ Relationship betrayal } \\
\hline Untrustworthiness & $\begin{array}{l}\text {-I told the whole school she liked [a boy]. She showed } \\
\text { me her diary }\end{array}$ \\
\hline Neglect & - She didn't pick me for her team in gym \\
\hline \multicolumn{2}{|l|}{ Resolution strategy } \\
\hline \multicolumn{2}{|l|}{ No overt resolution } \\
\hline Withdrawal & - He went home \\
\hline Ignore & - We ignored each other for a while \\
\hline Outsider intervenes & $\begin{array}{l}\text { - My dad told us to stop arguing } \\
\text { - My mom proved that [sister] did the dishes last week }\end{array}$ \\
\hline Capitulation & $\begin{array}{l}\text {-I went over to his house. I didn't want to sit there and } \\
\text { fight } \\
\text { - We gave them the 1st down, so we could have a } \\
\text { longer game }\end{array}$ \\
\hline \multicolumn{2}{|l|}{ Compromise } \\
\hline Joint solution & - We took turns [with the Atari] \\
\hline Separate solution & $\begin{array}{l}\text { - I watched TV in the bedroom and he watched in the } \\
\text { den }\end{array}$ \\
\hline \multicolumn{2}{|l|}{ Repair } \\
\hline $\begin{array}{l}\text { No overt repair } \\
\text { Resolved }\end{array}$ & [Made up at time of dispute/no repair needed] \\
\hline Ignore/let it slide & $\begin{array}{l}\text { - We started playing basketball again } \\
\text { - We just started talking about something else }\end{array}$ \\
\hline Outsider intervenes & $\begin{array}{l}\text { - My mom and dad told us to make up } \\
\text { - We went to W.'s party and she talked to L. to get } \\
\text { back friends. I talked to L. and she said no, she } \\
\text { didn't want to. W. said she wouldn't open any more } \\
\text { presents until we got back together and that's what } \\
\text { happened }\end{array}$ \\
\hline
\end{tabular}


Table I. Continued

\begin{tabular}{ll}
\hline $\begin{array}{l}\text { One person makes amends } \\
\text { Overt }\end{array}$ & - I said "Can we be friends?" She said "O.K." \\
& - She called to apologize \\
Indirect & -We started playing catch. I asked if he wanted to \\
& play \\
Mutual strategy & - He gave me some of his double baseball cards \\
& - We came to an agreement that it would never \\
happen again
\end{tabular}

of the friend dyad, so only overall means are presented. Frequency of fighting was negatively correlated with ratings of friend importance and relationship satisfaction (Table II). Additional analyses (not shown) revealed significant differences between respondents who during the interview denied any conflict with their best friend $(N=26)$ and those who did describe a conflict episode $(N$ $=86$ ). Youngsters who said they never fought, argued, or even disagreed with their best friend rated their friend as more important than those who did describe a quarrel $(M=4.5$ vs. $3.9 ; \mathrm{t}[109]=3.0, p<.005)$ and were more satisfied with their relationship ( $M=4.6$, vs. $4.1 ; \mathrm{t}[109]=2.1, p<.05)$.

\section{Siblings}

Effects of sibling constellation and family structure on frequency of sibling conflict have been described elsewhere (Raffaelli, 1992). In brief, frequency of conflict was unrelated to gender or age of the respondent or target sibling, family size, parental marital status, and whether the dyad shared a room. In contrast to findings for friends, intercorrelations between frequency of conflict and questionnaire measures of the relationship revealed that fighting was unrelated to emotional closeness, ratings of the sibling's importance, and relationship satisfaction; instead, frequency of conflict was related to spending tune together (Table II).

\section{Comparison of Siblings and Friend Ratings}

Ratings of relationships with siblings and friends differed in several ways (Table II). Although youngsters were equally satisfied with both relationships, friendships were characterized by higher levels of emotional closeness and shared time during daily life, and by lower levels of conflict, than sibling relationships. Despite these differences, it should be noted that youngsters rat- 
Table II. Questionnaire Ratings of Relationships with Siblings and Friends: Means, Standard Deviations, Correlations with Frequency of Conflict, and Relationship Comparisons $^{a}$

\begin{tabular}{|c|c|c|c|c|c|c|c|}
\hline & \multicolumn{3}{|c|}{ Friends } & \multicolumn{3}{|c|}{ Siblings } & \multirow{2}{*}{$\begin{array}{l}\text { Friends } \\
\text { vs. } \\
\text { Siblings: } \\
t^{c}\end{array}$} \\
\hline & $M$ & $S D$ & $r^{b}$ & $M$ & $S D$ & $r^{b}$ & \\
\hline Relationship satisfaction $^{d}$ & 4.2 & 1.0 & $-.25 * *$ & 4.0 & 1.2 & -.05 & 0.9 \\
\hline Emotional closeness ${ }^{d}$ & 3.1 & 0.95 & -.11 & 2.6 & 1.0 & -.01 & $4.9^{* * *}$ \\
\hline Importance ${ }^{d}$ & 4.1 & 0.9 & $-.38 * * *$ & 4.3 & 0.9 & .07 & $2.2^{*}$ \\
\hline Shared time $e^{e}$ & 3.8 & 1.0 & .06 & 3.0 & 1.0 & $.22^{*}$ & $5.5^{* * *}$ \\
\hline Voluntary association ${ }^{e}$ & 4.1 & 1.2 & .06 & 4.1 & 1.3 & .15 & 0.2 \\
\hline Frequency of conflict ${ }^{e}$ & 1.9 & 0.7 & 一 & 3.2 & 1.1 & - & $9.98 * * *$ \\
\hline
\end{tabular}

${ }^{a} N=112$; numbers vary due to missing data on some variables. All significance tests are two tailed.

${ }^{b}$ Correlation with frequency of conflict: ${ }^{*} p<.05 ;{ }^{* *} p<.01 ;{ }^{* * *} p<.001$.

${ }^{C}$ Comparisons between siblings and friends were carried out by means of paired t-tests; ${ }^{*} p<.05 ;{ }^{* *} p<.01 ;{ }^{* * *} \mathrm{p}<.001$.

${ }^{d}$ Response options range from 1 (not at all) to 5 (very much).

${ }^{e}$ Response options range from 1 (never) to 5 (more than once a day).

ed their siblings as slightly but significantly more important than friends. It appears that family ties outweigh factors that are significant in determining the quality of friendships, particularly the amount of conflict.

\section{Comparison of Sibling and Friend Conflict Episodes}

The question of whether siblings and friends differed in how they conducted conflict was examined using the following sequence of analyses. First, log-linear analysis was used to investigate the effects of age and gender on the distribution of conflict variables within each relationship. Where significant differences emerged, subsequent sibling and friend comparisons were carried out separately using the chi-square test of independence and follow-up tests for the difference between proportions. Because pervasive gender effects were found for friends but not siblings, for each variable the results for friends are presented first and gender differences discussed; then, sibling-friend comparisons are presented. 


\section{Onset of Conflict}

Precipitating Issue (Table III), Boys and girls differed markedly in the focus of their quarrels with friends. Boys described conflicts focusing on power issues or abusive behavior, whereas girls described conflicts stemming from relationship betrayal. Conflicts with siblings centered on different issues, with personal property disputes being more frequent and relationship betrayal less frequent; these differences were especially pronounced for girls.

Habitual vs. Specific. Conflicts were classified as habitual (recurring) or specific (one-time). Most boys described a specific conflict with both their friend (98\%) and sibling (95\%), but although the majority of the girls $(92 \%)$ described a specific fight with their best friend, 33\% described a habitual conflict with their sibling $\left(\chi^{2}=5.0, d f=1, p<.03\right)$.

Social Context. Siblings and friends fought in different surroundings, presumably because they interacted in different social spheres. The same proportion of sibling and friend conflicts took place when the dyad was alone (36\%), but more siblings fought in the presence of family members $(58 \%$, vs. $8 \%$ of friend dyads), and fewer in the presence of other peers $\left(6 \%\right.$, vs. $56 \% ; \chi^{2}=50.9$, $d f=2, p<.001)$.

Prior Activity. Among boys, conflicts with friends and siblings broke out in different settings. Shared activities (particularly sports, which were the setting for $33 \%$ of male friends' conflicts) were the setting for $55 \%$ of quarrels with

Table III. Precipitating Issues of Conflicts with Friends as Compared to Siblings ${ }^{a}$

\begin{tabular}{|c|c|c|c|c|c|c|}
\hline & \multicolumn{3}{|c|}{ Friends } & \multicolumn{3}{|c|}{ Siblings } \\
\hline & $\begin{array}{c}\text { Girls } \\
(N=39)\end{array}$ & $\begin{array}{c}\text { Boys } \\
(\mathrm{N}=42)\end{array}$ & $\begin{array}{c}\text { All } \\
(N=81)\end{array}$ & $\begin{array}{c}\text { Girls } \\
(N=39)\end{array}$ & $\begin{array}{c}\text { Boys } \\
(N=42)\end{array}$ & $\begin{array}{c}\text { All } \\
(N=81)\end{array}$ \\
\hline Power issues & 23.1 & $52.4^{*}$ & 38.3 & 38.5 & 45.2 & 42.0 \\
\hline Control behavior/ideas & 17.9 & 33.3 & 25.9 & 23.1 & 23.8 & 23.5 \\
\hline Sharing/turn-taking & 5.1 & $23.8^{b}$ & 12.4 & 15.4 & 21.4 & 18.5 \\
\hline Personal property & 5.1 & 4.8 & 4.9 & $28.2^{c}$ & $26.2^{c}$ & $27.2^{c}$ \\
\hline Abusive behavior & 15.4 & 26.2 & 21.0 & 20.5 & 16.7 & 18.5 \\
\hline Psychological abuse & 15.4 & 4.8 & 9.9 & 15.4 & 9.5 & 12.4 \\
\hline Physical abuse & 0.0 & $21.4^{b}$ & 11.1 & 5.1 & 7.1 & 6.2 \\
\hline Relationship betrayal & 56.4 & $16.7^{*}$ & 35.8 & $12.8^{\mathrm{c}}$ & 11.9 & $12.4^{\mathrm{c}}$ \\
\hline Untrustworthy behavior & 30.8 & 14.3 & 22.2 & 7.7 & 9.5 & $8.6^{c}$ \\
\hline Neglect & 25.6 & $2.4 \mathrm{~b}$ & 13.6 & $5.1^{\mathrm{c}}$ & 2.4 & $3.7^{\mathrm{c}}$ \\
\hline
\end{tabular}


friends (vs. 21\% of siblings), other activities (e.g., TV watching, chores) were the setting for $17 \%$ of friends' conflicts (vs. 33\% of siblings); $29 \%$ of boys described no prior activity with friends and $45 \%$ no prior activity with siblings $\left(\chi^{2}=10.0, d f=2, p<.01\right)$. For girls, most fights in both relationships tended to occur in the absence of a prior activity ( $49 \%$ of friends and $56 \%$ of siblings); similar to boys, girls were more likely to describe friend conflicts that erupted during interactions (36\% of friends vs. $17 \%$ of siblings) as compared to other activities ( $15 \%$ of friends vs. $27 \%$ of siblings), although these differences were not significant.

Instigator. Respondents were equally likely to describe sibling conflicts where they $(42 \%)$ or the sibling $(52 \%)$ initiated the fight. In contrast, where describing conflict with a friend, one quarter $(24 \%)$ of respondents blamed themselves, about a fifth $(21 \%)$ blamed both members of the dyad, and nearly one half blamed their friend. Perhaps respondents were reluctant to depict themselves as the offender in friend conflicts, whereas with siblings they had no such qualms.

Discussion: Onset of Conflict. Siblings and friends differed in the focus and social and interactional settings of their conflicts. Conflict in dyadic relationships has been described as a means of identifying relationship expectations (Rizzo, 1989), as individuals test the boundaries of acceptable behavior during their daily interactions. Friendship expectations, as revealed in conflicts, differ for boys and girls, with boys focusing on structuring their interactions and girls focusing on structuring their relationship. These findings match those from prior research (e.g., Piaget, 1932/1965; Selman, 1981; Youniss and Smollar, 1985). In contrast, conflicts between siblings often reflect the strains of group living and may lead to the clarification of family rules (Vuchinich, 1989) about sharing space, belongings, and personal boundaries.

\section{Process of Conflict}

Duration of Conflict. Boys and girls differed markedly in the average duration of friend conflicts, with boys describing short fights, and girls describing extended fights. Nearly half (49\%) of boys' quarrels with friends lasted under five minutes, compared to $6 \%$ of girls' quarrels; in contrast, $75 \%$ of the girls described friend conflicts that were drawn out over more than an hour, compared to $20 \%$ of the boys $\left.\chi^{2}=24.9, d f=3, p<.001\right)$. This difference is largely a function of the type of conflict reported, as conflicts stemming from relationship betrayal tended to be drawn out, whereas power struggles were more quickly resolved. 
Relationship differences In the duration of conflict were apparent for girls but not boys. About one third (35\%) of girls' fights with siblings lasted under five minutes, and $27 \%$ lasted over an hour, compared to $6 \%$ and $75 \%$ of fights with friends $\left(\chi^{2}=13.3, d f=3, p<.005\right)$. Again, this difference was partly attributable to the type of conflict experienced in each relationship.

Trajectory. The tendency of fight so escalate to violence was examined next by comparing the level of violence in 58 fights between friends and 71 fights between siblings where respondents spontaneously reported on the level of violence that occurred after the precipitating action. Siblings were more likely than friends to report either verbal $(29 \%$ vs. $3 \%)$ or physical aggression $(17 \%$ vs. $6 \%$ ) as compared to no aggression (54\% vs. $91 \% ; \chi^{2}=25.4, d f=2, p<$ $.001)$. Girls were as likely as boys to report that violence occurred during sibling conflicts.

Emotional Response to Conflict. Seventy-eight respondents provided information on feelings during conflict with their friend, and 74 on feelings during conflict with their sibling. The experience of conflict differed somewhat by relationship, but did not reach statistical significance. More youngsters reported anger during conflict with their sibling (66\% vs. 53\%) and fewer unhappiness ( $22 \%$ vs. $33 \%)$; the same proportion reported other emotions, including indifference or mixed feelings ( $12 \%$ vs. 14\%). When explaining their reactions, more respondents referred to the struggle to prevail in explaining their feelings during fights with siblings as compared to friends ( $71 \%$ vs. $58 \% ; z=1.95$, $p<.05)$, and fewer youngsters referred to the consequences of the fight ( $9 \%$ vs. $15 \%)$, or said they disliked this person (14\% vs. $25 \%)$.

Resolution Strategy. How youngsters handled conflicts with friends as compared to siblings was examined next (Table IV). Girls and boys differed in their tendency to resolve conflicts with friends overtly; nearly three quarters of girls described withdrawal followed by a period of noninteraction and over half of boys described an immediate resolution involving capitulation or compromise. Siblings and friends differed in how they resolved conflicts. Although outsiders were present at the same proportion of sibling and friend conflicts, siblings were more likely to experience outsider intervention, typically from parents. Additional differences were found for boys and girls separately. Girls showed a differential pattern of conflict resolution in each relationship; with friends, they tended not to resolve conflicts, whereas with siblings outsider intervention or capitulation was more often reported. More boys, on the other hand, showed $\&$ tendency to compromise with friends than siblings, and more boys reported giving in to their friend. 
Table IV.Resolution Strategy in Conflicts with Friends as Compared to Siblings ${ }^{a}$

\begin{tabular}{|c|c|c|c|c|c|c|}
\hline & \multicolumn{3}{|c|}{ Friends } & \multicolumn{3}{|c|}{ Siblings } \\
\hline & $\begin{array}{c}\text { Girls } \\
38^{b}\end{array}$ & $\begin{array}{c}\text { Boys } \\
42^{b}\end{array}$ & $\begin{array}{l}\text { All } \\
80^{b}\end{array}$ & $\begin{array}{c}\text { Girls } \\
37^{b}\end{array}$ & $\begin{array}{c}\text { Boys } \\
42^{b}\end{array}$ & $\begin{array}{l}\text { All } \\
79^{b}\end{array}$ \\
\hline No overt resolution & 73.7 & $35.7^{c}$ & 53.8 & $40.5^{d}$ & 28.6 & $34.2^{d}$ \\
\hline Withdraw & 5.3 & 19.0 & 12.5 & 13.5 & 19.0 & 16.5 \\
\hline Ignore & 5.3 & 0.0 & 2.5 & 5.4 & 4.8 & 5.1 \\
\hline Time lapse & 61.5 & $16.7^{c}$ & 38.8 & $21.6^{d}$ & $4.8^{c, d}$ & $12.7^{d}$ \\
\hline Outsider intervenes & 0.0 & 4.8 & 2.5 & $16.2^{d}$ & $35.7^{c, d}$ & $26.6^{d}$ \\
\hline Capitulation & 21.0 & 40.5 & 31.2 & 32.4 & 28.6 & 30.3 \\
\hline Self & 15.8 & 23.8 & 20.0 & 10.8 & $4.8^{d}$ & $7.6^{d}$ \\
\hline Other & 5.3 & 16.7 & 11.2 & $21.6^{d}$ & 23.8 & $22.8^{d}$ \\
\hline Compromise & 5.3 & 19.0 & 12.5 & 10.8 & 7.1 & 8.9 \\
\hline Joint & 2.6 & $19.0^{c}$ & 11.2 & 8.1 & 7.1 & 7.6 \\
\hline Separate & 2.6 & 0.0 & 1.3 & 2.7 & 0.0 & 1.3 \\
\hline
\end{tabular}

${ }^{a}$ Values represent proportion of respondents reporting each type of resolution (each column adds to $100 \%$ ).

${ }^{b} N$ values. Data not available for all respondents.

${ }^{c}$ Significant difference $(p<.05)$ between girls and boys within relationship.

${ }^{d}$ Significant differences $(p<.05)$ between siblings and friends.

Resolution strategies used by boys and girls in different types of conflicts with siblings and friends were examined next. Despite the small numbers in each cell, a pattern emerged suggesting that girls' fights with friends stemming from relationship betrayal or abuse were most likely to go unresolved; about $90 \%$ of fights in these categories were not resolved, compared to around half of similar fights with siblings. Girls were able to resolve the majority of power struggles with friends themselves, but over half of power struggles between siblings were either resolved by outsiders or left unresolved. Boys tended to resolve quarrels with friends stemming from abuse or power struggles through capitulation or compromise, but these types of conflicts with siblings went unresolved or required outsider intervention.

Discussion: Process of Conflict. Siblings and friends differed in how they conducted and resolved conflicts. Siblings engaged in open confrontation and often engaged in violence, pursuing the issue until one sibling gave in or a third person intervened. In contrast, friends did not express negative emotions to friends, and conflict was curtailed by both boys and girls. Boys tended to give in or compromise, achieving a rapid resolution to the problem, and girls to separate and not deal with the problem. Part of this gender difference in conflict resolution is due to the types of issues that friends quarreled about; boys' conflicts typically had a clearly defined focus but girl's conflicts often arose 
over tenuous issues of how friends should treat each other. Fear of relationship damage was evident in conflicts with friends; because siblings cannot rupture their relationship permanently, it is safe to express anger but friendships may end if negative emotions are vented.

\section{Aftermath of Conflict}

Repair Strategy. The distribution of strategies used to restore relationships to normal after the end of conflict are displayed in Table V. Once again, boys and girls differed in how they made up with their friends. Girls were more likely to engage in overt repair, whereas boys tended to have solved the problem at the time of the fight or ignore the dispute and resume normal relations without further discussion.

Boys showed differences between friends and siblings in how they repaired their relationship following conflict. Significantly more boys said that the friends had made up during conflict resolution; there was also a trend for friends to engage in mutual repair, discussing the problem and deciding how to remedy it together $(z=1.7, p<.10)$. In contrast, siblings were more likely to report that an outsider prompted repair or that one sibling made indirect amends to the other. There were no statistically significant differences in how girls described making up with siblings as compared to friends, although more

Table V.Repair Strategy in Conflicts with Friends as Compared to Siblings ${ }^{a}$

\begin{tabular}{|c|c|c|c|c|c|c|}
\hline & \multicolumn{3}{|c|}{ Friends } & \multicolumn{3}{|c|}{ Siblings } \\
\hline & $\begin{array}{c}\text { Girls } \\
36^{b}\end{array}$ & $\begin{array}{c}\text { Boys } \\
42^{b}\end{array}$ & $\begin{array}{l}\text { All } \\
78^{b}\end{array}$ & $\begin{array}{c}\text { Girls } \\
34^{b}\end{array}$ & $\begin{array}{c}\text { Boys } \\
35^{b}\end{array}$ & $\begin{array}{l}\text { All } \\
69^{b}\end{array}$ \\
\hline No overt repair & 41.7 & $76.2^{c}$ & 60.3 & 61.8 & $51.4^{d}$ & 56.5 \\
\hline Resolved & 22.2 & $52.4^{c}$ & 38.5 & 38.2 & $17.1^{c, d}$ & 27.5 \\
\hline Ignore dispute/let it sli & 19.4 & 23.8 & 21.8 & 23.5 & 34.4 & 27.0 \\
\hline Outsider prompts repair & 2.8 & 0.0 & 1.3 & 8.8 & $8.6^{d}$ & $8.7^{d}$ \\
\hline One makes amends & 38.9 & $9.5^{c}$ & 23.1 & 23.5 & $37.1^{d}$ & 30.4 \\
\hline Overt & 33.3 & $9.5^{d}$ & 20.5 & 14.7 & 14.3 & 14.5 \\
\hline Indirect & 5.6 & 0.0 & 2.6 & 8.8 & $22.9^{d}$ & $15.7^{d}$ \\
\hline Mutual & 16.7 & 14.3 & 15.4 & 5.9 & 2.9 & $4.4^{d}$ \\
\hline
\end{tabular}

${ }^{a}$ Values represent proportion of respondents reporting each type of repair strategy (each column adds to $100 \%$ ).

${ }^{b} N$ values. Data not available for all respondents.

${ }^{c}$ Significant difference $(p<.05)$ between girls and boys within relationship.

${ }^{d}$ Significant difference $(p<.05)$ between siblings and friends. 
girls reported using overt strategies with their friend, either making amends ( $z$ $=1.8, p<.10$ ) or engaging in mutual repair.

Time Lapse, For those cases where some form of repair occurred, the time lapse between conflict resolution and relationship repair was examined. Youngsters described waiting before making up with their friend but not their sibling. Of 42 youngsters who engaged in relationship repair with friends, $26 \%$ said less than an hour elapsed between resolution and repair, $21 \%$ said between one hour and half a day elapsed, and 52\% said over half a day passed. In contrast, of the 51 youngsters who engaged in relationship repair with siblings, $47 \%$ said under an hour elapsed, 39\% said between one hour and half a day passed, and $14 \%$ said over half a day passed. The greater tendency of friends to delay relationship repair was significant $\left(\chi^{2}=16.3, d f=2, p<.001\right)$.

Emotions After Conflict. Boys and girls differed in emotions after conflict with friends, with girls being less likely than boys to feel indifferent ( $0 \%$ vs. $17.5 \%)$ and more likely to feel either positive (77\% vs. $67.5 \%)$ or negative $\left(23 \%\right.$ vs. $\left.15 \% ; \chi^{2}=6.9, d f=2, p<.05\right)$. After conflict with siblings as compared to friends, youngsters were more likely to feel negative (27\% vs. 19\%) or indifferent (20\% vs. $9 \%)$ and less likely to report feeling positive (53\% vs. $\left.72 \% ; \chi^{2}=5.8, d f=2, p<.10\right)$. Typically, positive emotions were attributed to the restoration of normal relations or the cessation of conflict, and negative feelings to the conflict outcome, fear of relationship damage, or continued thinking about the fight.

Discussion: Aftermath of Conflict, Relationship differences in the aftermath of conflict emerged, with more girls "making up" with friends than siblings. The majority of boys did not engage in formal relationship repair; particularly for friends, conflicts tended to be resolved immediately and no further action was needed to restore the relationship to normal. In contrast, the majority of female friends made up, coming to some kind of understanding.

\section{CONCLUSIONS AND FUTURE DIRECTIONS}

This study has a number of limitations that should be kept in mind by the reader. These include the small sample size, ethnic composition of the sample, and reliance on self-report data from one member of the dyad. Although these limitations restrict the generalizability of the findings and conclusions that can be drawn, this study provides descriptive information on the structure of young adolescents' conflicts with siblings and friends, provides clues as to the developmental significance of conflict in these two relationships, and identifies directions for future research. 
The white middle-class teenagers who participated in this study described conflicts with their closest sibling and best friend that differ in fundamental ways. First, analysis of relationship ratings revealed that siblings quarrel more often than friends, a finding that replicates prior research (e.g., Furman and Buhrmester, 1985a, 1992). Second, different patterns of interrelations between frequency of conflict and relationship measures emerged for siblings and friends, suggesting that conflict has a different meaning in the two relationships. For siblings, frequency of fighting was unrelated to relationship ratings, including emotional closeness, relationship satisfaction, and ratings of the sibling's importance. In contrast, frequency of conflict with friends was linked to lower relationship satisfaction and ratings of the friend's importance, and youngsters who reported no conflict rated their friendship as more important and had higher levels of relationship satisfaction. Prior research has shown that friends who quarrel are likely to dissolve their relationship (Katz et al., 1992), and the present study supports the view that friendships may suffer when they are conflicted. Third, conflicts between siblings and friends differed in how they were structured and experienced, suggesting that conflict functions differently in each relationship.

The question of what implications these relationship differences hold can be addressed by examining what conflicts appear to be accomplishing and what youngsters might learn during them. During adolescence, youngsters face the dual challenge of forging an individual identity while maintaining interpersonal connections (Erikson, 1959, 1968; Havighurst, 1952/1972; Youniss and Smollar, 1985). Conflict interactions which permit frank expression of differences and self-interest are thought to foster a sense of uniqueness and individuality (Shantz and Hobart, 1985). The present study suggests that during adolescence, sibling conflict provides a forum where youngsters can assert themselves, whereas with friends they suppress their differences and subsume their goals to maintain peaceful relationships. One striking finding was that gender differences, which are so marked in friendships, are less pronounced in sibling conflicts; perhaps interactions with siblings provide girls with developmental opportunities that are not available in friendships. However, although being able to express emotions and desires freely may foster a sense of individuality, research on sibling violence suggests that conflict between siblings is the most frequent source of physical harm for youngsters (Goodwin and Roscoe, 1990), and the tendency for sibling quarrels to escalate to violence is worrisome for parents (Dunn, 1985). In addition, it is not clear whether the repetitive squabbles over mundane issues and personally differences that characterize the bulk 
of conflicts between siblings have a positive developmental impact. Conflict in friendships, which is characterized by restraint and a desire to maintain the relationship, can be expected to contribute to the second major task of adolescence, forging a sense of interpersonal connection. The ability to compromise, share, and engage in calm discussions about differences is an important component of adult behavior that appears to be manifested first during conflict with friends, as youngsters learn to subordinate their own interests in order to maintain the relationship. When (or whether) youngsters display such skills with siblings, and whether there is a connection between how conflicts with friends and siblings are negotiated, are topics worthy of attention in future research.

Additional research using different methodologies (e.g., observational techniques, interviews with both members of the dyad) is needed to replicate and extend the findings. Future research is also needed on the topic of how relationships with siblings and friends complement each other. Young children's interactions with peers, may be facilitated when they have siblings (Berndt and Bulleit, 1985; Pepler et al, 1982; Vandell and Mueller, 1980); recent research also suggests that children may use siblings to compensate for poor peer relationships (East, 1989). Because siblings cannot escape from each other, they provide sources of interactions for even peer-rejected youngsters. Finally, the issue of how conflict is integrated into different relationships should be investigated; the findings presented here suggest that conflict is not necessarily detrimental to the sibling relationship and may function as a unique developmental force during adolescence.

\section{ACKNOWLEDGMENTS}

I would like to acknowledge the schools and students who participated in this research, and thank Reed Larson and the other members of my dissertation committee (Bertram Cohler, Mihalyi Csikszentmihalyi, Peggy Miller, and Marvin Zonis); Elena Duckett for help in developing coding schemes; and the CRTPA fellows for their feedback and support.

\section{REFERENCES}

Bank, \& P., and Kahn, M. D. (1982). The Sibling Bond, Basic, New York.

Berkowitz, M. W. (Ed.) (1985). Peer Conflict and Psychological Growth. New Directions for Child Development, 29. Jossey-Bass, San Francisco.

Berndt. T. J. (1989). Contributions of peer relationships to children's development. In Berndt, T. J., and Ladd, G. W. (eds.). Peer Relationships in Child Development. Wiley, New York.

Berndt, T. J, and Bulleit, T. N. (1955). Effects of sibling relationships on preschoolers' behavior at home and at school. Develop. Psychol. 21: 761-767. 
Berscheid, E. (1986). Emotional experience in close relationships: Some implications for child development. In Hartup, W. W., and Rubin, Z. (Eds.), Relationships and Development. Erlbaum, Hillsdale, NJ.

Blyth, D. A. (1982). Mapping the social world of adolescents: Issues, techniques, and problems. In Serafica, F. (ed), Social Cognition, Context, and Social Behavior. A developmental Perspective. New York: Guilford.

Blyth, D. A., Hill, J. P., and Thiel, K. S. (1982). Early adolescents' significant others: Grade and gender differences in perceived relationships with familial and nonfamilial adults and young people. J. Youth Adoles. 11: 425-450.

Buhrmester, D., and Furman, W. (1990). Perceptions of sibling relationships during middle childhood and adolescence. Child Develop. 61: 1387-1398.

Caplan, M., Bennetto, L., and Weissberg, R. P. (1991). The role of interpersonal context in the assessment of social problem-solving skills. J. Appl. Develop. Psychol. 12: 103-114.

Collins, W. A., and Laursen, B. (1992). Conflict and relationships during adolescence. In Shantz, C. U. and Hartup, W. W. (eds.), Conflict in Child and Adolescent Development. Cambridge University Press, New York.

Crick, N. R. (April, 1989). Children's perceptions of agressive, prosocial, and withdrawn behavior. Gender differences. Paper presented at the Society for Research in Child Development, Kansas City, MO.

Dunn, J. (1985). Sisters and Brothers, Harvard University Press, Cambridge, MA.

Dunn, J. (1988). The Beginnings of Social Understanding. Harvard University Press, Cambridge, MA.

East, P. L. (April, 1989). Missing provisions in peer-withdrawn and aggressive children's friendships: Do siblings compensate? Paper presented at the Society for Research in Child Development, Kansas City, MO.

Erikson, E. (1959). Identity and the life cycle. Psychol. Issues 1: 18-64.

Erikson, E. (1968). Identity, Youth, and Crisis. Norton, New York.

Faber, A., and Mazlish, E. (1987). Siblings Without Rivalry. Avon, New York.

Forman, E. A., and Kraker, M. J. (1985). The social origins of logic: The contributions of Piaget and Vygotsky. In Berkowitz, M. W. (ed.), Peer Conflict and Psychological Growth. New Directions for Child Development, 29. Jossey-Bass, San Francisco.

Freud, S. (1955). The Interpretation of Dreams. Basic, New York.

Furman, W., and Buhrmester, D. (1985a). Children's perceptions of the personal relationships in their social networks. Develop. Psychol. 21: 1016-1024.

Furman, W., and Buhrmester, D. (1985b). Children's perceptions of the qualities of sibling relationships. Child Develop. 56: 448-451.

Furman, W., and Buhrmester, D. (1992). Age and sex differences in perceptions of networks of personal relationships. Child Develop. 63: 103-115.

Goodwin, M. P., and Roscoe. B. (1990). Sibling violence and agonistic interactions among middle adolescents. Adolescence 15: 451-467.

Hartup, W. W. (1983). Peer relations. In Hetherington, M. E. (Ed.) and M. P. Mussen (Series Ed.), Handbook of Child Psychology, Vol 4. Socialization, Personality, and Social Development. Wiley, New York.

Hartup, W. W., Laursen, B., Stewart, M. I., and Eastenson, A. (1988). Conflict and the friendship relations of young children. CUM Develop. 59: 1590-1600.

Havighurst, R. J. (1952/1972). Developmental Tasks and Education. David McKay, New York.

Hay, D. F. (1984). Social conflict in early childhood. In Whitehurst, G. (ed.), Annals of Child Development (Vol. 1). 
Hill, J., and Holmbeck, G. (1987). Disagreements about rotes in families with seventh graders. J. Youth Adolesc. 16: 312-319.

Katz, L. F., Kramer, L., and Gottman, J. M. (1992). Conflict and emotions in marital, sibling, and peer relationships. In Shantz, C. U., and Hartup, W. W. (eds.), Conflict in Child and Adolescent Development. Cambridge University Press, New York.

Lamb, M. E., and Sutton-Smith, B. (1982). Sibling Relationships: Their Nature ami Significance Across the Lifespan. Erlbaum, Hillssdale, NJ.

Larson, R. W., and Richards, M. H. (1989). Journal of Youth and Adolescenee, 18 (special issue: The Changing Life Space of Early Adolescence).

Montemayor, R. (1983). Parents and adolescents in conflict: All families some of the time and some families most of the time. J. Early Adolesc. 3: 83-103.

Montemayor, R, and Hanson, E. (1985). A naturalistic view of conflict between adolescents and their parents and siblings. J. Early Adolesc. 5: 23-30.

Nelson, J., and Aboud, F. E. (1985). The resolution of social conflict between friends. CUM Develop. 56: 1009-1017.

Pepler, D., Corter, C., and Abramovitch, R. (1982). Social relations among children: Comparison of sibling and peer interaction. In Rubin, K. H., and Ross, H. S. (eds.), Peer Relationships and Social Skills in Childhood, Springer-Verlag, New York.

Piaget, J. (1933/1965). The Moral Judgment of the Child. Free Press, New York.

Raffaelli, M. (1992). Sibling conflict in early adolescence. J. Marriage Family 54: 652-663.

Rizzo, T. (1989). Friendship Development Among Children in School. Ablex, Norwood, NJ.

Roscoe, B., Goodwin, M. P, and Kennedy, D. (1987). Sibling violence and agonistic interactions experienced by early adolescents. J. Family Viol. 2: 121-137.

Selman, R. L. (1981). The child as a friendship philosopher. In Asher, S. R. and Gottman, J. M. (eds.), The Development of Children's Friendships. Cambridge University Press, New York.

Selman, R. L., Beardslee, W., Schultz, L. H., Krupa, M., and Podorefsky, D. (1986). Assessing adolescent interpersonal negotiation strategies: Toward the integration of functional and structural models. Develop. Psychol. 22: 450-459.

Shantz, C U. (1987). Conflicts between children. Child Develop. 58: 283-305.

Shantz, C U., and Hartup, W. W. (1992). Conflict and development: An introduction. In Shantz, C. U. and Hartup, W. W. (eds.), Conflict in Child and Adolescent Development. Cambridge University Press, New York.

Shantz, C. U., and Hobart, C. J. (1989). Social conflict and development: Peers and siblings. In Berndt, T. J. and Ladd, G. W. (eds.), Peer Relationships in Child Development. Wiley, New York.

Shantz, C. U., and Shantz, D. W. (1985). Conflict between children: Social-cognitive and sociometric correlates. In Berkowitz, M.W. (ed.), Peer Conflict and Psychological Growth. New Directions for Child Development (Vol. 29): Jossey-Bass, San Francisco.

Sutton-Smith, B., and Resenberg, B. G. (1970). The Sibling. Holt, Rhinehart, New York,

Tsukada, G. K. (1979). Sibling interaction: A review of the literature. Smith College Stud. Social Work 49: 229-247.

Vandell, D. L, and Mueller, E. C. (1980). Peer play and friendships during the first two years. In Foot, H. C, Chapman, A. J., and Smith, J. R. (eds.), Friendship and Social Relations in Children. John Wiley, New York

Vuchinich, S. (1987). Starting and stopping spontaneous family conflicts. J. Marraige Family 49: 591601.

Yeates, K. O., Schultz, L. H., and Selman, R. L. (1991). The development of interpersonal negotiation strategies in thought and action: A social-cognitive link to behavioral adjustment and social status. 